\title{
ANALISIS BUDAYA KERJA SEBAGAI TENAGA KERJA INDONESIA (TKI) MASYARAKAT DESA BOKE KECAMATAN SAPE KABUPATEN BIMA DALAM MENINGKATKAN KESEJAHTERAAN
}

\author{
Aan Andrian, Dewi Ratna Muchlisa Mandyara \\ dratnamuchlisa@yahoo.co.id \\ aan_andrian@gmail.com
}

\begin{abstract}
ABSTRAK
Sejahtera dan bahagia merupakan situasi dan kondisi yang sangat didambakan oleh semua orang. Setiap orang menginginkan hidup yang ideal di masa depannya. Maka dari itu hampir tiap orang berusaha membuat bagaimana hidup idealnya itu terwujud dengan tekad mencapai harapan itulah yang mengharuskan masyarakat desa Boke bekerja sampai ke negara lain sebagai Tenaga Kerja Indonesia (TKI) dari bertahun-tahun lalu sehingga timbul menjadi sebuah budaya yang tetap dilestarikan sampai sekarang. Budaya kerja masyarakat Desa Boke adalah suatu pandangan hidup yang sudah menjadi kebiasaan yang telah dibudayakan oleh masyarakat dan selalu tercermin dalam sikap dan perilaku.Penelitian ini ingin menggali penerapan budaya sebagai TKI dalam meningkatkan kesejahteraan dan pengaruh tingkat kesejahteraan masyarakat dengan hadirnya budaya kerja tersebut.Hasil penelitian ini dapat membantu pihak-pihak terkait terutama pemerintah dalam hal menentukan kebijakan-kebijakan yang mengatur tentang TKI.Wawancara dilakukan terhadap 10 orang informan penelitian. Temuan penelitian menyatakan bahwa kebiasaan masyarakat yang bekerja diluar negeri merupakan sebuah wujud dari kebudayaan dan budaya kerja sebagai TKI masyarakat desa Boke dapat meningkatkan kesejahteraan. Namun dalam hal ini pemerintah harus lebih memperhatikan para TKI agar mendapatkan perlindungan hukum yang baik.
\end{abstract}

Kata Kunci: Budaya Kerja, Kesejahteraan

\section{PENDAhUluAN}

Pada dasarnya semua manusia, keluarga, komunitas dan masyarakat memiliki kebutuhan sosial yang harus dipenuhi agar mereka dapat mencapai yang dimaksud dengan kebahagiaan sosial.Kebutuhan tersebut merujuk pada kebutuhan biologis, pendidikan, kesehatan yang layak dan juga interaksi sosial yang harmonis.Akhirnya kesejahteraan sosialpun mampu menciptakan kesempatan sosial bagi penduduknya untuk meningkatkan dan merealisasikan potensi-potensi yang ada. Dalam pola dasar kesejahteraan sosial bahwa hakikat pembangunan kesejahteraan sosial adalah upaya peningkatan kualitas kesejahteraan sosial perorangan, kelompok, dan komunitas masyarakat yang memiliki harkat dan martabat, dimana setiap orang mampu mengambil peran dan menjalankan fungsinya dalam kehidupan (Balatbangsos, 2003).

Kesejahteraan atau yang biasa disebut kesejahteraan sosial merupakan serangkaian aktifitas yang terorganisir yang ditunjukan untuk meningkatkan kualitas hidup, relasi sosial, serta peningkatan kehidupan masyarakat yang selaras dengan standard dan norma-norma masyarakat sebagai suatu tujuan dan merupakan cita-cita, pedoman dan aspirasi agar terpenuhinya kebutuhan materi,

\section{4 | Program Studi Pendidikan Ekonomi, Sekolah Tinggi Keguruan dan IImu Pendidikan (STKIP)} Bima 


\section{"Jurnal PenKoMi : Kajian Pendidikan dan Ekonomi" STKIP Bima Vol. 2, No. 1 Januari 2019

sosial dan spiritual. Terkait dengan hal ini Spicker yang dikutip Isbandi (2007;56)menggambarkankaitan dengan kebijakan sosial sekurang-kurangnya mencakup lima bidang utama yang disebut dengan big five yaitu: bidang kesehatan, bidang pendidikan, bidang perumahan, bidang jaminan sosial, dan bidang pekerjaan sosial inilah idealnya yang juga di harapkan di masyarakat Desa Boke agar tingkat kesejahteraan itu bisa tercapai.

Budaya kerja adalah suatu falsafah dengan didasari pandangan hidup sebagai nilai-nilai yang menjadi sifat, kebiasaan dan juga pendorong yang dibudayakan dalam suatu kelompok dan tercermin dalam sikap menjadi perilaku, cita-cita, pendapat, pandangan serta tindakan yang terwujud sebagai kerja atau bekerja (Gering, Supriyadi dan Triguno, 2001: 7).Dengan demikian budaya kerja masyarakat Desa Boke adalah suatu pandangan hidup yang sudah menjadi kebiasaan yang telah dibudayakan oleh masyarakat dan selalu tercermin dalam sikap dan perilaku.

Adanya tuntutan terhadap tingkat kesejahteraan mendorong masyarakat Desa Boke untuk berpikir dan bekerja keras dalam mencukupi kebutuhan hidup yang setiap harinya mendesak, sehingga masyarakat memilihjalan untuk bekerja di negara asing atau yang sering disebut dengan Tenaga Kerja Indonesia (TKI) dengan modal kemampuan yang minim serta segala resiko yang harus ditanggung oleh individu tersebut. Budaya kerja yang demikian didasarkan atas adanya harapan untuk bisa memperbaiki kondisi ekonomi keluarga.

Hasil observasi awal yang dilakukan oleh peneliti di lokasi penelitian diketahui bahwa budaya kerja pada masyarakat di Desa Boke cenderung memilih untuk bekerja di negara asing dengan berbagai alasan, seperti:sempitnya lapangan pekerjaan,kurangya lahan garapan dan upah yang cukup tinggi dengan harapan bisa menjamin kesejahteraan keluarga yang mereka tinggalkan. Budaya kerja yang demikian masih berlangsung sampai sekarang, dimana setiap tahunnya masyarakat berbondong-bondong untuk bekerja ke luar negeri.Fenomena yang demikian telah menjadi pandangan yang terus terwariskan dalam kehidupan masyarakat Desa Boke. Berdasarkan data awal yang diperoleh oleh peneliti dari kantor Desa Boke Kecamatan Sape Kabupaten Bima, diketahui bahwa setiap tahunnya masyarakat Desa Boke yang bekerja di luar negeri sebanyak 30 orang. Umumnya masyarakat yang bekerja di luar negeri rata-rata tamatan Sekolah Menengah Atas (SMA) dan kebanyakan laki-laki.

Berdasarkan fenomena di atas, maka peneliti terdorong untuk melakukan kajian lebih lanjut dan mendalami tentang fenomena budaya kerja masyarakat di Desa Boke Kecamatan Sape Kabupaten Bima. Dengan demikian, peneliti mengangkat judul penelitian, yaitu: Analisis Budaya Kerja Sebagai Tenaga Kerja Indonesian (TKI) Masyarakat Desa Boke Kecamatan Sape Kabupaten Bima Dalam Meningkatkan Kesejahteraan. Penelitian ini diharapkan dapat menemukan solusi terhadap permasalahan budaya kerja yang berkaitan dengan aspek peningkatan kesejahteraan masyarakat.

Dalam buku Pedoman Pengembangan Budaya Kerja Aparatur Negara (2002:3) dapat dikatakan bahwa budaya kerja mengandung beberapa pengertian, yaitu:

\section{5 | Program Studi Pendidikan Ekonomi, Sekolah Tinggi Keguruan dan Ilmu Pendidikan (STKIP) Bima}




\section{"Jurnal PenKoMi : Kajian Pendidikan dan Ekonomi" STKIP Bima Vol. 2, No. 1 Januari 2019

a. Pola Nilai, sikap, tingkah laku, hasil karsa dan karya termasuk segala instrumen, system kerja, teknologi dan bahasa yang digunakan.

b. Budaya berkaitan dengan persepsi terhadap nilai-nilai dan lingkungannya yang melahirkan makna dan pandangan hidup, yang akan mempengaruhi sikap dan tingkah laku dalam bekerja.

c. Budaya merupakan hasil dari pengalaman hidup, kebiasaan-kebiasaan, serta proses seleksi (menerima atau menolak) norma yang ada dalam cara berinteraksi social atau menempatkan dirinya ditengah-tengah lingkungan kerja tertentu.

d. dalam proses budaya terdapat saling mempengaruhi dan saling ketergantungan (interdepensi), baik social maupun lingkungan sosial.

Budaya kerja merupakan sekumpulan pola atau perilaku kerja yang melekat secara keseluruhan pada diri setiap individu atau masyarakat dalam sebuah wilayah. Membangun budaya kerja juga dapat meningkatakan dan mempertahankan sisi-sisi positif, serta berupaya membiasakan pola perilaku tertentu agar tercipta suatu bentuk baru yang lebih baik.

Budaya kerja merupakan kegiatan yang dilakukan secara berulang oleh individu dalam melakukan pekerjaan dan akhirnya menjadi sebuah kebiasaan pada suatu organisasi/lingkungan. Budaya kerja berbeda antara organisasi satu dengan yang lainnya, hal itu dikarenakan landasan dan sikap perilaku yang dicerminkan oleh setiap orang dalam organisasi beerbeda. Budaya kerja yang terbentuk secara positif akan bermanfaat karena setiap anggota dalam suatu organisasi membutuhkan sumbang saran, bahkan kritik yang bersifat membangun dari ruang lingkup pekerjaannya demi kemajuan dilembaga pendidikan tersebut, namun budaya kerja akan berakibat buruk jika pegawai dalam suatu organisasi mengeluarkan pendapat yang berbeda hal dikarenakan adanya perbedaan setiap individu dalam mengeluarkan pendapat, tenaga dan pikirannya karena setiap individu mempunyai kemampuan dan keahliannya sesuai bidang masing-masing.

Untuk memperbaiki budaya kerja yang baik membutuhkan waktu bertahuntahun untuk mengubahnya, maka itu perlu ada pembenahan-pembenahan yang dimulai dari sikap dan tingkah laku pimpinannya kemudian diikuti para bawahannya, terbentuknya budaya kerja diawali tingkat kesadaran pemimpin atau pejabat yang ditunjuk dimana besarnya kemudian diikuti para bawahannya sehingga akan membentuk suau cara tersendiri apa yang dijalankan dalam perangkat satuan kerja atau organisasi.

Budaya kerja tidak akan muncul begitu saja, akan tetapi harus diupayakan dengan sungguh-sungguh melalui proses yang terkendali dengan melibatkan semua sumber daya manusia dalam seperangkat sistem, alat-alat dan teknik-teknik pendukung. Budaya kerja akan menjadi kenyataan melalui proses panjang, karena perubahan nilai-nilai lama menjadi nilai-nilai baru akan memakan waktu untuk menjadi kebiasaan dan tak henti-hentinya terus melakukan penyempurnaan dan perbaikan. Adapun komponen-komponen budaya kerja yaitu menurut Ndraha (2005 : 209), yaitu sebagai berikut:

a. Anggapan dasar tentang kerja

\section{6 | Program Studi Pendidikan Ekonomi, Sekolah Tinggi Keguruan dan Ilmu Pendidikan (STKIP) Bima}




\section{"Jurnal PenKoMi : Kajian Pendidikan dan Ekonomi" STKIP Bima Vol. 2, No. 1 Januari 2019

Pendirian atau anggapan dasar atau kepercayaan dasar tentang kerja, terbentuknya melalui kostruksi pemikiran silogistik.Premisnya adalah pengalaman hidup empirik dan kesimpulan.

b. Sikap terhadap pekerjaan

Manusia menunjukan berbagai sikap terhadap kerja.Sikap adalah kecenderungan jiwa terhadap sesuatu.Kecenderungan itu berkisar antara menerima sepenuhnya atau menolak sekeras-kerasnya.

c. Perilaku ketika bekerja

Dan sikap terhadap bekerja, lahir perilaku ketika bekerja.Perilaku menunjukan bagaimana seseorang bekerja.

d. Lingkungan kerja dan alat kerja

Dalam lingkungan, manusia membangun lingkungan kerja yang nyaman dan menggunakan alat (teknologi) agar ia bekerja efektif, efisien, dan produktif.

e. Etos kerja

Istilah etos diartikan sebagai waktu atau semangat fundemental budaya, berbagai ungkapan yang menunjukan kepercayaan, kebiasaan, atau perilaku suatu kelompok masyarakat. Jadi etos berkaian era dengan budaya kerja..

\section{Kesejahteraan}

Kesejahteraan sosial adalah kondisi sejahtera dari suatu masyarakat.Kesejahteraan sosial meliputi kesehatan, keadaan ekonomi, kebahagiaan, dan kualitas hidup rakyat". Sedangkan Wilensky dan Lebeaux (1965) merumuskan kesejahteraan sosial sebagai sistem yang terorganisasi dari pelayanan-pelayanan dan lembaga-lembaga sosial, yang dirancang untuk membantu individu-individu dan kelompok-kelompok agar mencapai tingkat hidup dan kesehatan yang memuaskan.Maksudnya agar tercipta hubunganhubungan personal dan sosial yang memberi kesempatan kepada individuindividu pengembangan kemampuan-kemampuan mereka seluas-luasnya dan meningkatkan kesejahteraan mereka sesuai dengan kebutuhan-kebutuhan masyarakat.Sedangkan menurut Midgley (1995:14) Kondisi kesejahteraan sosial diciptakan atas kompromi tiga elemen.Pertama, sejauh mana masalah-masalah sosial ini diatur, kedua sejauh mana kebutuhan-kebutuhan dipenuhi, ketiga sejauh mana kesempatan untuk meningkatkan taraf hidup dapat disediakan.

Kesejahteraan sosial adalah keseluruhan usaha sosial yang terorganisir dan mempunyai tujuan utama untuk meningkatkan taraf hidup masyarakat berdasarkan konteks sosialnya.Di dalamnya tercakup pula unsur kebijakan dan pelayanan dalam arti luas yang terkait dengan berbagai kehidupan dalam masyarakat, seperti pendapatan, jaminan sosial, kesehatan, perumahan, pendidikan, rekreasi, budaya, dan sebagainya.

Salah satu landasan hukum yang dijadikan acuan adalah undang-undang nomor 6 tahun 1974 tentang ketentuan-ketentuan pokok kesejahteraan sosial. Dalam penjelasan umum ditetapkan bahwa "lapangan kesejahteraan sosial adalah sangat luas dan kompleks, mencakup antara lain, aspek-aspek pendidikan, kesehatan, agama, tenaga kerja, kesejahteraan sosial (dalam arti sempit), dll ". Hal ini sesuai dengan pendapat Kamerman dan Kahn (1979) yang menjelaskan 6 komponen atau subsistem dan kesejahteraan sosial, yaitu : (1) pendidikan, (2)

\section{7 | Program Studi Pendidikan Ekonomi, Sekolah Tinggi Keguruan dan Ilmu Pendidikan (STKIP) Bima}




\section{"Jurnal PenKoMi : Kajian Pendidikan dan Ekonomi" STKIP Bima Vol. 2, No. 1 Januari 2019

kesehatan, (3) pemeliharaan penghasilan, (4) pelayanan kerja, (5) perumahan, (6) pelayanan sosial personal.

Sejahtera dan bahagia merupakan situasi dan kondisi yang sangat didambakan oleh semua orang. Seseorang dikatakan sejahtera apabila ia mempunyai pekerjaan yang sesuai dengan bakat yang dimiliki serta hasil pekerjaan tersebut dapat memenuhi kebutuhan hidup, minimal kebutuhan sandang, pangan, dan perumahan. Jika kebutuhan ini telah terpenuhi, menurut Maslow manusia sudah bisa dikatakan sejahtera dalam hidupnya. (Indiro Gito sudarmo dan I Nyoman Sudita,1997: 30-31)

Setiap orang menginginkan hidup yang ideal di masa depannya.Maka dari itu hampir tiap orang berusaha membuat bagaimana hidup idealnya itu terwujud. Tapi sayangnya, banyak problema-problema sosial yang terjadi yang membuat terhambatnya proses dalam mencapai kehidupan yang ideal tersebut. Problema sosial atau bisa kita sebut sebagai masalah sosial merupakan suatu kondisi yang lahir tetapi tidak ideal atau kondisi yang tidak diinginkan yang terjadi di masyarakat.Kondisi yang tidak ideal tersebut dapat menganggu ketentraman dalam kehidupan masyarakat tersebut.

Kondisi-kondisi ini dapat dilihat dari beberapa indikator yang menjadi penentu apakah masyarakat tersebut sejahtera atau tidak. Indikator-indikator kesejahteraan tersebut antara lain adalah kependudukan (population), kesehatan dan gizi, pendidikan, ketenaga kerjaan, taraf dan pola konsumsi, perumahan dan lingkungan, kemiskinan, sosial dan lainnya. Dengan menganalisis indikatorindikator tersebut kia dapat tahu apakah masyarakat tersebut mengalami kesejahteraan atau tidak.Dengan tidak memenuhinya indikator-indikator tersebut maka terbuktilah masyarakat tersebut memiliki tingkat kesejahteraan yang rendah sehingga problema-problema sosial yang terjadi dapat beraneka ragam dan bisa menimbulkan ketimpangan-ketimpangan serta kesenjangan di masyarakat.

Selanjutnya akan dijelaskan sebagian dari indikator-indikator kesejahteraan masyarakat yang mungkin telah kita lihat pada realita-realita di sekitar kita apakah masyarakat tersebut memenuhi indikator tersebut. Dimana banyak alasan yang mendasari tidak memenuhinya indikator kesejahteraan tersebut.Kemiskinan merupakan salah satu indikator kesejahteraan artinya kemiskinan sangat mempengaruhi keadaan masyarakat itu sendiri.

Kemiskinan adalah suatu keadaan yang dimana ketidakmampuan untuk memenuhi kebutuhan dasar dalam kehidupannya.Kita dapat melihat banyak sekali contoh-contoh nyata di sekitar kita.Hidup mereka yang sangat minim dengan keterbatasan pendapatan yang mereka miliki sudah bisa kita nilai tingkat kesejahteraannya.Jadi dapat kita simpulkan bahwa semakin kecilnya tingkat kemiskinan daerah tersebut, berarti bisa dikatakan bahwa masyarakat tersebut sejahtera.

Pada mulanya, pendapatan per kapita digunakan untuk mengukur tingkat kesejahteraan masyarakat suatu Negara, sebab dapat menggambarkan laju perkembangan tingkat kesejahteraan berbagai Negara.Namun dalam perkembangannya, pendapatan per kapita yang digunakan mengukur tingkat kesejahteraan masyarakat mempunyai banyak kelemahan-kelemahan.

\section{8 | Program Studi Pendidikan Ekonomi, Sekolah Tinggi Keguruan dan Ilmu Pendidikan (STKIP) Bima}


Pendapatan per kapita yang dianggap sebagai pengukur tingkat kesejahteraan tidak menggambarkan komposisi umur, distribusi pendapatan masyarakat, komposisi pendapatan nasional, corak pengeluaran, perubahanperubahan dalam keadaan pengangguran (Ahmad mahyudi,2004: 151). Kesejahteraan dalam pembangunan sosial ekonomi,

Faktor utama dari tingkat kesejahteraan ekonomi penduduk adalah daya beli, sehingga apabila daya beli menurun, maka berdampak pada menurunnya kemampuan untuk memenuhi perbagai kebutuhan hidup yang menyebabkan tingkat kesejahteraan menurun.Pengeluaran rumah tangga merupakan salah satu indikator yang dapat memberikan gambaran keadaan kesejahteraan penduduk.

\section{METODE PENELITIAN}

Penelitian ini dilaksanakan di Desa Boke yaitu salah satu Desa yang terletak di antara desa Jia dan desa Sari Kecamatan Sape Kabupaten Bima Provinsi Nusa Tenggara Barat (NTB). Luas wilayah mencapai sebesar $4,7337 \mathrm{~km}^{2}$ dengan seabagian besar wilayahnya merupakan daerah pegunungan sehingga sebagian besar masyarakatnya tidak terlalu banyak yang menggarap lahan pertanian. Melihat letak dan posisi geografis yang sebagian besar adalah wilayah pegunungan maka tidak begitu banyak pendapatan yang bisa dihasilkan oleh masyarakat desa Boke. Kondisi geografis inilah yang melatar belakangi masyarakatdesa boke mencari alternatif lain demi mendapatkan penghasilan yang layak. Penelitian mengunakan pendekatan kualitatif.

Instrumen yang digunakan dalam mengumpulkan data adalah Observasi dan wawancara bertahap.Analisis data menggunakan interactive model, yang unsurunsurnya meliputi reduksi data (data reduction), penyajian data (data display), dan conclutions drowing/verifiying. Alur teknik analisis data dapat dilihat seperti gambar di bawah ini:

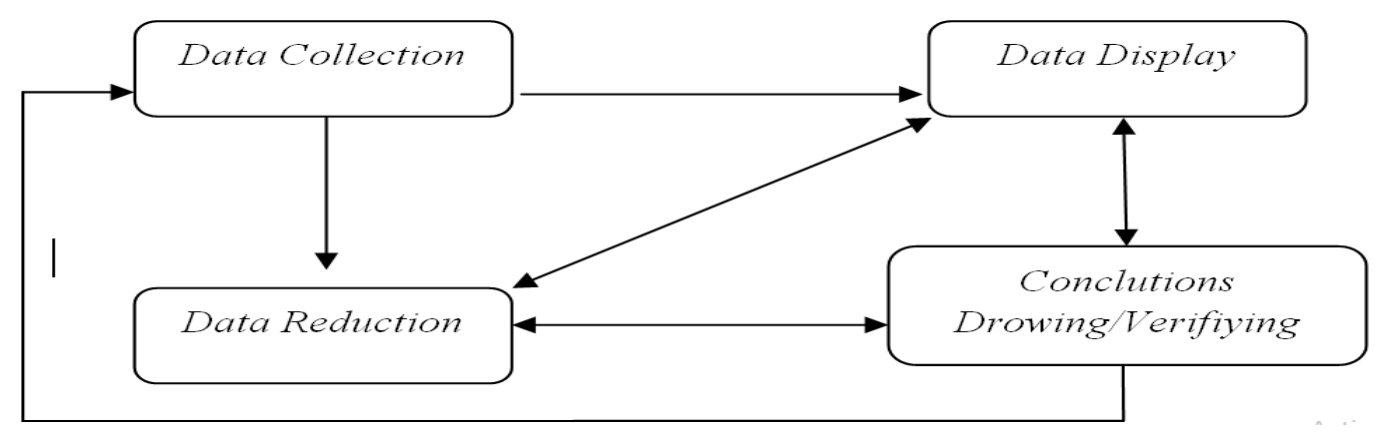

Gambar 1. Komponen Interactive Model (Sugiyono, 2007).

\section{HASIL PENELITIAN DAN PEMBAHASAN}

Data hasil penelitian yang dideskripsikan berikut sesuai dengan fokus atau sub fokus penelitian yang telah dirumuskan sebelumnya. Adapun data hasil penelitian masing-masing sub fokus penelitian secara berturut-turut dapat dideskripsikan sebagai berikut :

\section{Analisis Wujud kebudayaan dari masyarakat Desa Boke}

99 | Program Studi Pendidikan Ekonomi, Sekolah Tinggi Keguruan dan Ilmu Pendidikan (STKIP) Bima 


\section{"Jurnal PenKoMi : Kajian Pendidikan dan Ekonomi" STKIP Bima Vol. 2, No. 1 Januari 2019

Analisis wujud kebudayaan dari masyarakat desa boke ini dilakukan untuk mengetahui apakah kebiasaan masyarakat yang bekerja menjadi Tenaga Kerja Indonesia (TKI) dapat dikatakan wujud dari sebuah kebudayaan. Menurut J.J. Hoenigman, wujud kebudayaan dibedakan menjadi tiga: gagasan, aktivitas, dan artefak.

Dari hasil penelitian yang telah dilakukan oleh penulis kebiasan masyarakat desa boke yang bekerja menjadi TKI ini bisa digolongkan menjadi sebuah kebudayaan yang berwujud dari aktivitas masyarakat itu sendiri.Aktivitas adalah wujud kebudayaan sebagai suatu tindakan berpola dari manusia dalam masyarakat itu.Wujud ini sering pula disebut dengan sistem sosial.Sistem sosial ini terdiri dari aktivitas-aktivitas manusia yang saling berinteraksi, mengadakan kontak, serta bergaul dengan manusia lainnya menurut pola-pola tertentu yang berdasarkan adat tata kelakuan.Sifatnya konkret, terjadi dalam kehidupan sehari-hari, dan dapat diamati dan didokumentasikan.

\section{Analisis komponen}

Analisis komponen ini dilakukan untuk mengetahui dan menjelaskan bahwa budaya kerja masyarakat sebagai TKI ini merupakan komponen kebudayaan non material.Kebudayaan nonmaterial adalah ciptaan-ciptaan abstrak yang diwariskan dari generasi ke generasi, misalnya berupa dongeng, cerita rakyat, dan lagu atau tarian tradisional. Budaya kerja masyarakat sebagai TKI ini merupakan sebuah ciptaan abstrak yang diwariskan dari generasi ke generasi, ini dibuktikan dengan hasil wawancara Pak Burhanuddin selaku Kades Boke menyatakan bahwa :

"kebiasaan masyarakat desa Boke mencari pekerjaan di luar negeri ini sudah ada dari saya masih kecil, bahkan dulu sangat banyak warga yang pergi karena proses pengurusan surat-suratnya gampang dan tidak memerlukan tingkat pendidikan yang tinggi, yang penting bisa bekerja dan berkomunikasi dengan lancar", hasil wawancara (Selasa, 14 Agustus 2018)

Dari kutipan ini terlihat jelas bahwa kegiatan masyarakat sebagai TKI ini sudah ada sejak lebih dari 5 tahun yang lalu, dan ini selalu diwariskan dari generasi ke generasi.

\section{Analisis terbentuknya budaya kerja masyarakat sebagai TKI}

Budaya kerja menjadi TKI di desa Boke sendiri awalnya muncul dikarenakan dorongan kebutuhan hidup yang harus terpenuhi. Faktor ekonomilah yang menjadi alasan utama kenapa budaya kerja ini muncul,jugha wilayah desa yang sebagian besar merupakan daerah pegunungan dengan tingkat suhu yang lumayan tinggi mengakibatkan masyarakat tidak bisa bertani secara maksimal selain pada musim hujan saja, sehingga masyarakat berpikir untuk bagaimana bisa tetap memenuhi kebutuhan hidup yang semakin tingggi tiap harinya dengan menjadi TKI, hal ini dibuktikan dengan hasil wawancara yang peneliti lakukan dengan bapak Budiman orangtua salah satu TKI sebagai berikut :

"faktor utama yang menyebabkan ini bisa terjadi adalah kebutuhan ekonomi yang semakin hari semakin tinggi, jadi kebanyakan masyarakat disini memilih jalan untuk menjadi TKI agar bisa memenuhi kebutuhan hidup tersebut", hasil wawancara (Selasa, 14 Agustus 2018).

Selain faktor diatas ada beberapa faktor pendukung lain yang menjadi pemicu budaya ini timbul salah satunya yaitu kurangnya ketersediaan pekerjaan

\section{I0D | Program Studi Pendidikan Ekonomi, Sekalah Tinggi Keguruan dan IImu Pendidikan (STKIP) Bima}




\section{"Jurnal PenKoMi : Kajian Pendidikan dan Ekonomi" STKIP Bima Vol. 2, No. 1 Januari 2019

diwilayah negara sendiri terlebih khusus di Desa Boke, hal ini dikarenakan banyaknya tenaga kerja yang tersedia sehingga menyebabkan persaingan diantara para tenaga kerja misalnya dari segi kualifikasi pendidikan dan kemampuan dasar yang sangat minim dimiliki oleh tenaga kerja yang dari wilayah pedesaan seperti desa boke, sehingga melatar belakangi masyarakat lebih memilih bekerja di negara lain yang tidak membutuhkan tingkat pendidikan yang tinggi dan hanya bermodalkan kemampuan berkomunikasi yang baik dan lancar. Hal ini dibuktikan dengan pernyataan bapak Burhanuddin,S.Pd selaku kades Boke dibawah ini :"masyarakat yang bekerja diluar negeri kebanyakan tidak memiliki tingkat kualifikasi pendidikan yang tinggi rata-rata hanya tamatan SMA bahkan ada yang tamatan SMP juga yang penting mereka mau bekerja dan mengikuti pelatihan khususnya pelatihan berbahasa agar bisa berkomunikasi dengan baik dan lancar", hasil wawancara (Rabu, 15 Agustus 2018).

Budaya kerja sebagai tki merupakan warisan keluarga yang di wariskan dari kegenarasi sehingga sampai hari ini masyarakat masih ada yang berangkat menjadi TKI alasan hadirnya budaya ini jugha Tergiur upah yang lebih tinggi juga merupakan faktor selanjutnya yang menjadi pertimbangan para tenaga kerja, dengan bermodalkan kemampuan berkomunikasi yang baik dan lancar mereka bisa mendapatkan upah yang jauh lebih tinggi dibanding bekerja dinegara sendiri. Walaupun mereka harus menanggung resiko jauh dari keluarga dan tanah air tapi demi harapan kehidupan ekonomi yang stabil sehingga dapat mensejahterahkan keluarga dan memperoleh kehidupan yang layak, hal ini dibuktikan dengan pernyataan yang diberikan oleh bapak Husni selaku mantan TKI sebagai berikut :

Semenjak adanya budaya tki ini sangat mambantu sekali dalam hal peningkatan kesejahteraan hidup masyarakat disini bahkan di desa sari jugha bisa dilihatlah peningkatan kesejahteraanya semulanya rumah kayu biasa sekarang pada punya rumah batu yg layak, kemudian jugha ada yang beli mobil, tanah dsb", hasil wawancara (kamis 15 agustus 2018).

\section{Analisis penerapan budaya kerja sebagai TKI}

Analisi penerapan budaya kerja ini dilakukan agar mengetahui hal-hal apa saja yg harus di persiapakan masyarakat untuk menjadi TKI yang legal serta apa saja kendala yang biasa di jumpai selama menjadi TKI. Adapun hal-hal tersebut akan dijelaskan oleh peneliti sebagai berikut :

1) Hal-hal yang harus dipersiapkan untuk menjadi TKI legal

a. Kesiapan mental

b. Mendaftar pada PJTKI (Swasta)

c. Surat-surat perijinan,

d. Mengikuti pelatihan khusus, dan

e. Biaya-biaya

Hal-hal yang harus dipersiapkan diatas merupakan hasil wawancara yang dilakukan penulis dengan para narasumber yang telah dirangkum secara spesifik oleh penulis, hal ini dibuktikan dengan salah satu pernyataan yang disampaikan oleh bapak Husni sebagai mantan TKI dan ibu Sri Susisusanti sebagai TKI yang masih aktif bekerja di negara luar.

Bapak Husni : 


\section{"Jurnal PenKoMi : Kajian Pendidikan dan Ekonomi" STKIP Bima Vol. 2, No. 1 Januari 2019

"Sebelum berangkat kami harus menyiapkan dulu beberapa hal seperti KTP, ijazah, dan beberapa surat dari pihak Desa, serta kami juga mengikuti pelatihan selama \pm 3 bulan, hasil wawancara (Kamis, 15 Agustus 2018).

Ibu Sri Susisusanti :

"setelah saya memutuskan untuk bekerja diluar negeri,, saya menyiapkan biayabiaya, mendaftar pada PJTKI dan menyiapkan beberapa dokumen administrasi seperti KTP, dll”, hasil wawancara lewat telepon (Sabtu, 17 Agustus 2018).

2) Kendala-kendala yang dihadapi selama menjadi TKI

Semua pekerjaan dan kegiatan yang kita lakukan di dunia ini pasti memiiki beberapa hal baik itu kelebihan maupun kekurangan begitu juga dengan bekerja sebagai TKI, selama bekerja para TKI pasti mengalami beberapa kendala baik itu dari segi komunikasi maupun dari segi adaptasi yang kurang maksimal dengan daerah baru. Hal ini dibuktikan dari beberapa pernyataan yang diberikan oleh bapak Afriansyah selaku TKI yang masih bekerja dan ibu Erlina selaku mantan TKI yang diwawancarai oleh peneliti sebagai berikut :

Bapak Afriansyah :

"tentu pasti ada kendala yang kami hadapi, saya pribadi mengalami kendala pada saat awal-awal kesana karena saya belum terlalu lancar berkomunikasi menggunakan bahasa disana dan cuaca disana yang 4 musim membuat saya sempat sakit karena belum terbiasa", hasil wawancara lewat telepon (Senin, 19 Agustus 2018).

Ibu Erlina :

"kendala yang saya hadapi pada saat disana itu, ketika awal-awal saya sampai disana, karena saya masih kurang lancar berkomunikasi dan belum menguasai tempat-tempat disana jika saya disuruh majikan ke pasar itu sangat sulit untuk saya”, hasil wawancara (Kamis, 15 Agustus 2018).

\section{Analisis Tingkat Kesejahteraan Masyarakat}

Salah satu landasan hukum yang dijadikan acuan adalah undang-undang nomor 6 tahun 1974 tentang ketentuan-ketentuan pokok kesejahteraan sosial. Dalam penjelasan umum ditetapkan bahwa "lapangan kesejahteraan sosial adalah sangat luas dan kompleks, mencakup antara lain, aspek-aspek pendidikan, kesehatan, agama, tenaga kerja, kesejahteraan sosial (dalam arti sempit), dll ".

Kondisi-kondisi ini dapat dilihat dari beberapa indikator yang menjadi penentu apakah masyarakat tersebut sejahtera atau tidak. Indikator-indikator kesejahteraan tersebut antara lain adalah kependudukan (population), kesehatan dan gizi, pendidikan, ketenaga kerjaan, taraf dan pola konsumsi, perumahan dan lingkungan, kemiskinan, sosial dan lainnya. Dengan menganalisis indikatorindikator tersebut kita dapat mengetahui apakah masyarakat tersebut mengalami kesejahteraan atau tidak.Dengan tidak memenuhinya indikator-indikator tersebut maka terbuktilah masyarakat tersebut memiliki tingkat kesejahteraan yang rendah sehingga problema-problema sosial yang terjadi dapat beraneka ragam dan bisa menimbulkan ketimpangan-ketimpangan serta kesenjangan di masyarakat.

1) Kependudukan (population) 
Kependudukan yang dikaji dalam penelitian ini merupakan jumlah penduduk desa Boke yang usia kerja dan memiliki pekerjaan sebagai TKI yaitu berjumlah sekitar 86 orang.

2) Kesehatan dan gizi

Masyarakat desa Boke yang bekerja sebagai TKI dan mantan TKI bisa dikatakan sejahterah ini dibuktikan dari data yang diperoleh penulis di kantor Desa yang mengatakan sebanyak 469 orang warga desa Boke terdaftar sebagai peserta asuransi dan sebagian besar mereka yang terdaftar adalah TKI, mantan TKI dan anggota keluarga dari TKI. Selain itu angka kematian anak dan balita karena gizi buruk tidak pernah terjadi selama kesehatan dan asupan nutrisinya memadai. Data nya sebagai berikut :

Tabel 1. Asuransi Kesehatan Dan Kasus Gizi Buruk

\begin{tabular}{|c|c|c|c|c|}
\hline \multirow[t]{2}{*}{ No. } & \multicolumn{2}{|c|}{$\begin{array}{c}\text { Tingkat kepesertaan Asuransi kesehatan } \\
\text { (BPJS) }\end{array}$} & \multicolumn{2}{|c|}{ Derajat Kesehatan Dan Gizi Buruk } \\
\hline & $\begin{array}{c}\text { TKI } \\
\text { dan } \\
\text { Mantan } \\
\text { TKI }\end{array}$ & Bukan TKI & $\begin{array}{c}\text { TKI } \\
\text { dan } \\
\text { mantan } \\
\text { TKI }\end{array}$ & Bukan TKI \\
\hline 1. & $\begin{array}{c}460 \\
\text { orang }\end{array}$ & 9 orang & 0 & 2 kasus \\
\hline $\begin{array}{l}\text { Jml } \\
\mathrm{h}\end{array}$ & \multicolumn{2}{|c|}{469 orang } & \multicolumn{2}{|c|}{2 kasus } \\
\hline
\end{tabular}

Sumber: Data monografi desa Boke

Jadi dapat disimpulkan bahwa masyarakat desa Boke yang bekerja sebagai TKI sudah sejahtera dibidang kesehatan karena semua TKI maupun anggota keluarganya memiliki jaminan kesehatan (asuransi).

3) Pendidikan

Rata-rata anggota keluarga baik itu anak maupun saudara dari anggota TKI menempuh pendidikan sampai ke jenjang perguruan tinggi, ini dibuktikan dari data yang diperoleh penulis di kantor Desa sebagai berikut:

Tabel 2. Perbandingan Tingkat Pendidikan Masyarakat

\begin{tabular}{|c|l|c|c|}
\hline \multirow{2}{*}{ No. } & \multicolumn{1}{|c|}{ Tingkat Pendidikan } & $\begin{array}{c}\text { TKI dan mantan } \\
\text { TKI }\end{array}$ & Bukan TKI \\
\hline & Sekolah Dasar (SD) / Sederajat & 42 orang & 34 orang \\
\hline & Sekolah Menengah Pertama (SMP) /Sederajat & 37 orang & 12 orang \\
\hline Sekolah Menengah Atas (SMA) /Sederajat & 41 orang & 9 orang \\
\hline Perguruan Tinggi & 12 orang & 4 orang \\
\hline & Jumlah & 132 orang & 59 orang \\
\hline
\end{tabular}

Sumber: data monografi desa Boke

4) Pola konsumsi

Faktor selanjutnya dari tingkat kesejahteraan penduduk adalah daya beli, sehingga apabila daya beli menurun, maka berdampak pada menurunnya kemampuan untuk memenuhi berbagai kebutuhan hidup yang menyebabkan tingkat kesejahteraan menurun.Pengeluaran rumah tangga merupakan salah satu indikator yang dapat memberikan gambaran keadaan kesejahteraan

103 | Program Studi Pendidikan Ekonomi, Sekolah Tinggi Keguruan dan Ilmu Pendidikan (STKIP) Bima 


\section{"Jurnal PenKoMi : Kajian Pendidikan dan Ekonomi" STKIP Bima Vol. 2, No. 1 Januari 2019}

penduduk. Semakin tinggi pendapatan, maka porsi pengeluaran akan bergeser dari pengeluaran untuk makanan ke pengeluaran untuk bukan makanan. Di desa Boke sendiri tingkat konsumsi rumah tangga sangat tinggi itu dibuktikan dari hasil wawancara yang dilakukan oleh penulis dengan ibu Nurhaya salah satu masyarakat desa Boke yang menyaksikan secara langsung kehidupan masyarakat yang menjadi TKI sebagai berikut:

"yang saya lihat sejauh ini mereka yang bekerja sebagai TKI belanjanya banyak-banyak, keluarga yang disini serba kecukupan, saya juga kadangkadang dapat dari tetangga yang saudaranya kerja diluar seperti baju, dll”, hasil wawancara (15 Agustus 2018).

5) Perumahan dan lingkungan

Tempat tinggal masyarakat baik yang masih bekerja maupun sudah berhenti bekerja rata-rata rumah jenis permanen yang luas dengan model yang modern, hal ini dibuktikan dengan hasil observasi yang dilakukan oleh peneliti secara langsung dan data yang diperoleh penulus dari kantor desa setempat sebagai berikut :

Tabel 3. Perbandingan jenis Rumah masyarakat

\begin{tabular}{|l|l|l|}
\hline \multicolumn{1}{|c|}{ Jenis Rumah } & \multicolumn{1}{c|}{ TKI dan Mantan TKI } & \multicolumn{1}{c|}{ Bukan TKI } \\
\hline Permanen & 143 rumah & 46 rumah \\
\hline Semi permanen & 59 rumah & 26 rumah \\
\hline Panggung & 12 rumah & 62 rumah \\
\hline Jumlah & 214 rumah & 134 rumah \\
\hline
\end{tabular}

Sumber: data monografi desa Boke

Sebagai bukti lain penulis melampirkan potret - potret rumah TKI dan mantan TKI yang ada di Desa Boke sebagai berikut :

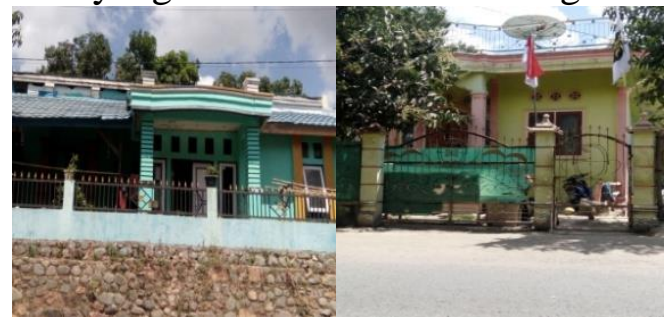

Sumber: data hasil penelitian 2018

Gambar 2. Potret rumah-rumah TKI dan mantan TKI

6) Kemiskinan

Kemiskinan merupakan salah satu indikator kesejahteraan artinya kemiskinan sangat mempengaruhi keadaan masyarakat itu sendiri.Kemiskinan adalah suatu keadaan yang dimana ketidakmampuan untuk memenuhi kebutuhan dasar dalam kehidupannya. Kita dapat melihat banyak sekali contoh-contoh nyata di sekitar kita.Hidup mereka yang sangat minim dengan keterbatasan pendapatan yang mereka miliki sudah bisa kita nilai tingkat kesejahteraannya.Jadi dapat kita simpulkan bahwa semakin kecilnya tingkat kemiskinan daerah tersebut, berarti bisa dikatakan bahwa masyarakat tersebut sejahtera.

104 | Program Studi Pendidikan Ekonomi, Sekolah Tinggi Keguruan dan Ilmu Pendidikan (STKIP) Bima 


\section{"Jurnal PenKoMi : Kajian Pendidikan dan Ekonomi" STKIP Bima Vol. 2, No. 1 Januari 2019

Didesa Boke sendiri tingkat kemiskinan sudah semakin kecil ini dibuktikan dengan hasil observasi dan wawancara yang dilakukan langsung oleh penulis serta data pendapatan penduduk yang di peroleh penulis di kantor Desa setempat sebagai berikut :

Tabel 4. Tingkat Pendapatan Masyarakat Desa Boke

\begin{tabular}{|l|l|}
\hline \multicolumn{2}{|c|}{$\begin{array}{c}\text { Tingkat Pendapatan Masyarakat } \\
\text { Desa Boke per bulan }\end{array}$} \\
\hline \multicolumn{1}{|c|}{ TKI } & \multicolumn{1}{|c|}{ Bukan TKI } \\
\hline $\begin{array}{l}\text { Rp. 3.500.000,- s/d } \\
\text { Rp. } 8.000 .000,-\end{array}$ & Rp. $1.000 .000,-$ s/d \\
Rumber : data monografi desa Boke dan hasil wawancara
\end{tabular}

7) Sosial

Indikator sosial yang dimaksud penulis dalam penelitian ini adalah bagaimana kehidupan sosial seperti komunikasi dan pergaulan dari masyarakat yang bekerja sebagai TKI dengan masyarakat yang tidak bekerja sebagai TKI, dari hasil observasi dan wawancara yang dilakukan penulis proses komunikasi dan pergaulan dari masyarakat tersebut masih sangat baik bahkan lebih baik lagi, dan rasa solidaritas yang dimiliki masyarakat masih sangat baik ini dibuktikan dengan hasil wawancara yang dilakukan penulis dengan bapak A. Latif sebagai masyarakat biasa yang ikut terlibat dalam kehidupan sosial dengan masyarakat yang bekerja sebagai TKI sebagai berikut :

"mereka sangat baik, tidak berubah dan tidak sombong, ketika saya dan yang lainnya butuh bantuan pinjaman uang untuk beberapa keperluan mereka meminjamkan dan bahkan tidak pernah menagih bayar hanya saya memiliki kesadaran sendiri ketika sudah punya saya bayar hutang saya", hasil wawancara (kamis, 15 Agustus 2018)

Berdasarkan hasil wawancara tersebut dapat dilihat bahwa masyarakat yang bekerja dan pernah bekerja sebagai TKI selalu senantiasa saling membantu sesamanya.

\section{Analisis Aspek Hukum}

Perlindungan hukum terhadap TKI dilaksanakan mulai dari pra penempatan sampai dengan masa purna penempatan. Pra penempatan adalah kegiatan (1) pengurusan surat izin penyerahan (SIP), (2) perekrutan dan seleksi, (3) pendidikan dan pelatihan kerja, (4) pemeriksaan kesehatan dan psikologi, (5) pengurusan dokumen, (6) uji kompetensi, (7) pembekalan akhir untuk pemberangkatan, (8) pembuatan perjanjian kerja, (9) masa tunggu diperusahaan, (10) pembiayaan.

Berdasarkan perlindungan hukum terhadap TKI baik pada pra penempatan, masa penempatan dan purna penempatan sebagaimana diuraikan diatas, berdasarkan analisis merupakan bentuk perlindungan hukum dari aspek hukum administrasi dan aspek hukum pidana. Hal ini dapat dilihat dari ketentuan dalam Undang-Undang No. 39 Tahun 2004 tentang penempatan dan perlindungan TKI diluar negeri.

Upaya-upaya yang dilakukan dalam perlindungan hukum TKI diluar negeri yang dikirim PJTKI dan Non PJTKI

105 | Program Studi Pendidikan Ekonomi, Sekolah Tinggi Keguruan dan Ilmu Pendidikan (STKIP) Bima 


\section{"Jurnal PenKoMi : Kajian Pendidikan dan Ekonomi" STKIP Bima Vol. 2, No. 1 Januari 2019

Pemerintah bertugas mengatur, membina, melaksanakan dan mengawasi penyelenggaraan penempatan dan perlindungan TKI diluar negeri. Dalam melaksanakan tugas dan tanggung jawab untuk meningkatkan upaya perlindungan TKI diluar negeri pemerintah berkewajiban :

a. Menjamin terpenuhinya hak-hak calon TKI baik yang berangkat melalui pelaksana penempatan TKI, maupun yang berangkat secara mandiri

b. Mengawasi pelaksanaan penempatan calon TKI

c. Membentuk dan mengembangkan sistem informasi penempatan calon TKI diluar negeri

d. Melakukan upaya diplomatik untuk menjamin pemenuhan hak dan perlindungan TKI secara optimal di negara tujuan, dan

e. Memberikan perlindungan kepada TKI selama masa sebelum pemberangkatan, penempatan dan purna penempatan (Pasal 5 s/d 7 Undang-Undang No. 39 Tahun 2004 tentang penempatan dan perlindungan Tenaga Kerja Indonesia Diluar Negeri).

Disnakertrans dalam perlindungan TKI baik pada pra penempatan, masa penempatan dan purna penempatan.

a. Pra penempatan memberikan pengarahan pada calon TKI untuk mendaftar lewat Dinas Tenaga Kerja dan Transmigrasi Kabupaten setempat atau cabang PJTKI yang mempunyai izin atau rekomendasi rekrut di kabupaten setempat. Memberikan pembekalan awal pemberangkatan kepada calon TKI yang akan diberangkatkan ke tempat penampungan.

b. Pada masa penempatan apabila terjadi masalah Disnakertrans selalu koordinasi kepada PJTKI yang memberangkatkan sehingga masalah tersebut dapat diselesaikan.

c. Pada masa purna penempatan memberikan pembinaan kepada TKI yang sudah pulang agar hasil yang didapat dari luar negeri dapat dimanfaatkan dan dikembangkan dengan sebaik-baiknya demi masa depan keluarga mereka.

Selama ini upaya perlindungan TKI diluar negeri yang dilakukan oleh Disnakertrans antara lain adalah proses penyelesaian masalah TKI didalam negeri, alur pengajuan klaim asuransi, pengiriman uang TKI (program remittancn) dan perpanjangan perjanjian kerja.

Dari data hasil penelitian yang diperoleh penulis maka dapat dikatakan bahwa budaya kerja sebagai Tenaga Kerja Indonesia (TKI) masyarakat Desa Boke mampu meningkatkan kesejahteraan hal ini dapat dilihat dari analisis kesejahteraan.

\section{KESIMPULAN}

Dari hasil analisis yang telah dilakukan pada masyarakat desa Boke yaitu dari aspek kesejahteraan maka dapat diambil beberapa kesimpulan yaitu :

1. Kebiasaan masyarakat yang cenderung bekerja di negara luar sebagai Tenaga Kerja Indonesia (TKI) merupakan wujud dari sebuah kebudayaan yang berasal dari aktivitas masyarakat dan tergolong dalam komponen kebudayaaan non material.

\section{IDG | Program Studi Pendidikan Ekanomi, Sekolah Tinggi Keguruan dan IImu Pendidikan (STKIP) Bima}




\section{"Jurnal PenKoMi : Kajian Pendidikan dan Ekonomi" STKIP Bima Vol. 2, No. 1 Januari 2019 e-ISSN: 2614-6002}

2. Budaya kerja ini timbul dengan dilatar belakangi beberapa faktor, yaitu faktor ekonomi, kurangnya ketersediaan lapangan pekerjaan, tergiur upah yang lebih tinggi serta kebiasaan.

3. Dalam penerapannya ada beberapa hal yang harus dipersiapak oleh para calon TKI diantaranya yaitu kesiapan mental, mendaftar pada PJTKI, surat-surat perijinan, mengikuti pelatihan dan menyiapkan biaya keberangkatan. Selama bekerja para TKI ini menemukan beberapa kendala yang umumnya dirasakan pada bulan-bulan awal keberangkatan seperti kurang lancar dalam berkomunikasi, kurang bisa beradaptasi dengan lingkungan ditempat bekerja.

Masyarakat yang bekerja sebagai TKI sudah sangat sejahterah ini dibuktikan dengan terpenuhinya indikator-indikator kesejahteraan seperti kependudukan, kesehatan dan gizi yang terpenuhi, pendidikan yang terjamin untuk keluarga, pola konsumsi yang semakin hari semakin meningkat, perumahan dan lingkungan yang sudah sangat layak, nyaman dan memadai, angka kemiskinan yang semakin menurun ini dibuktikan dengan tingkat pendapatan masyarakat yang semakin tinggi dan kehidupan sosial masyarakat yang semakin membaik dan tetap mengutamakan kebersamaan.

\section{DAFTAR RUJUKAN}

Ahmadi, Abu dan Widodo Supriyono. 2004. Psikologi Belajar. Jakarta: Rineka Cipta.

Sugiyono. 2010. Metode Penelitian Kualitatif Kuantitatif dan R\&D. Bandung : CV. Alfabeta

Suharto, Edi. 2006. Membangun Masyarakat Memberdayakan Rakyat. Bandung:PT. Refika Pratama

Fatmasari, Dewi. 2015. Analisis sosial ekonomi dan budaya masyarakat pesisir desa Waruduwur Kecematan Mundu, Kabupaten Cirebon.

Buniarto. 2012. Hubungan Antara Kinerja Keuangan Daerah, Pertumbuhan Ekonomi Dan Pertumbuhan Investasi Terhadap Kesejahteraan Masyarakat, Khususnya di Era Otonomi Daerah. Jurnal Studi Universitas Brawijaya

Arvian, Dimas.2008. Klasifikasi Kesejahteraan Rumah Tangga di Jawa Timur dengan Pendekatan Multivariate Adaptive Regression Spline Bootstrap Aggregating (Mars Bagging).Jurnal Studi Universitas Surabaya.

Arsyad, Lincolin. 1992. Ekonomi Pembangunan Edisi Kedua. Yogyakarta :Bagian Penerbitan Sekolah Tinggi Ilmu Ekonomi, YKPN

Ndakularak, Erwin. 2008. Analisis Faktor-Faktor yang MempengaruhiKesejahteraan Masyarakat Kabupaten/Kota di Provinsi Bali. Jurnal StudiUniversitas Udayana.

Fitriani, YF. 2014. Kebudayaan dan kehidupan ekonomi masyarakat pedesaan Pamekasan

Madura.JurnalPemerintahan.PeranDinasSosialTenagaKerjaDanTransmig rasiKabupatenNunukan

DalamMenananganiTenagaKerjaIndonesia(StudiKasusTKIYangDideport asiDari Malaysia)ejournal.ip.fisip-unmul.ac.id@Copyright(2015) 
"Jurnal PenKoMi : Kajian Pendidikan dan

Ekonomi" STKIP Bima Vol. 2, No. 1 Januari 2019

e-ISSN: 2614-6002

Sari, DA.2016. Analisis Faktor-faktor yang mempengaruhi kesejahteraan masyarakat di Kota Bandarlampung.

Wissler, C. 1916. Psychological and Historical Interpretations for culture. Sciens. XLV.

108 | Program Studi Pendidikan Ekonomi, Sekolah Tinggi Keguruan dan Ilmu Pendidikan (STKIP) Bima 